\title{
Materials Development Frameworks and the Challenges of Developing Learning Materials
}

\section{Niall Walsh}

Nagoya University of Foreign Studies

\section{Brian Cullen}

Nagoya Institute of Technology

\section{Reference Data}

Walsh, N., \& Cullen, B. (2021). Materials development frameworks and the challenges of developing learning materials. In P. Clements, R. Derrah, \& P. Ferguson (Eds.), Communities of teachers \& learners. JALT. https://doi.org/10.37546/JALTPCP2020-37

While ESL textbooks are the primary source of learning materials for many teachers, others favor developing materials to suit their own specific teaching context. Whether deciding to embrace third party materials, or go it alone, a common prerequisite for developing quality materials exists for both mass producers and individual teachers. The creation of teaching materials often benefits from following a framework. This research addresses three areas of materials design within a Japanese context: how well educators believe that textbooks meet the needs of their students, the challenges teachers encounter in materials design, and whether ESL teachers in Japan adhere to a materials development framework. The findings suggest that most teachers are satisfied with their textbooks. A major challenge that teachers encounter in materials design is a lack of time. Finally, a clear divide exists between teachers who adhere to a structured process of materials design and those that do not.

教科書は多くの教師の主な学習教材となっているが、教えている場面に沿つた教材を開発したいと考える教師もいる。第三 者が開発した教科書を選ぶか、自身の教材を開発するかを決定する時共通の必要条件は良質の教材である。教材開発は、フ レームワークに従うことがしばしば有効である。本研究は、日本の状況下において、以下の三つの分野について論述する。すな わち、ESLの教科書が学生の二ーズにどれくらい応えているか、教師が教材開発で直面する課題、日本のESL教師が教材開発 のフレームワークを遵守しているか、である。結果として、ほとんどの教師は使用する教科書に满足していることがわかった。教 材開発の主な課題は、時間の不足であった。最後に、教材開発において構造化されたプロセスを遵守している教師とそうでな い教師との間に明確な溝が存在することがわかった。
$\boldsymbol{T}$ he materials that a teacher uses in the classroom are a core tool of language teaching. In many situations, the coursebook is a predominant feature of a classroom and a primary contributor to the language learning experience. Yet, a study by Tomlinson (2010) found that 78\% of ESL teachers surveyed were not satisfied with the coursebook they were using. A major concern of educators is that these materials treat all learners the same (Maley, 2011). As a result, many teachers may choose to develop their own materials for their specific teaching context. However, unlike large scale publishers, whose materials development processes are monitored and well documented, Tomlinson and Masuhara (2018) point out that there is a lack of research into the processes teachers negotiate when developing their own language materials. The lack of evidence is slightly concerning because, along with pedagogical style, the material used can be one of the most important determinants of student performance, and therefore requires structured planning and execution. The study at hand addresses the existing dearth of information on the materials development processes of language educators by documenting the experience of a sample of English as a Second Language (ESL) teachers in Japan. Specifically, it focuses on how well educators believe that textbooks meet the needs of their students, the challenges teachers encounter in materials design, and whether ESL teachers in Japan adhere to a materials development framework.

\section{Materials Development Framework}

Publishing companies invest large sums of money in producing teaching materials, and their primary objective is to increase sales and profitability which is achieved by selling a textbook to as many users as possible without necessarily taking account of local circumstances and needs. A very specific context such as producing a textbook that caters solely to the needs of a group of middle-aged men studying English to talk about mountain climbing may not be very lucrative, yet there may be a real need for such highly specific learning materials. This is an extreme example, but there are clearly needs in any teaching context that cannot be fulfilled by an externally produced textbook, which 
by its nature, is unable to take into account local needs while also providing content for unknown learners. In many such specific situations, it is the teacher's responsibility to fill these niche areas by producing tailored learning materials.

When looking specifically at the Japanese ESL context, there is insufficient documented research into three areas concerning ESL teachers in Japan and materials development. Firstly, what are the attitudes held by teachers towards coursebooks, and what is their preference regarding commercially produced materials and their own material? Secondly, for those teachers who choose to create their own materials, what are the major difficulties they encounter when developing materials? Finally, when producing materials, are language teachers in Japan guided by a materials development framework?

Before addressing these questions, it is useful to consider the process of materials development and how it can be conceptualized with a development framework.

Various principled frameworks for materials development have been proposed (see McDonough \& Shaw 2003; Mishan \& Timmis 2015). These frameworks attempt to combine educational theory with practical use in the classroom and help to create consistency in the goals and realization of materials. In this paper, we use a practical framework developed by Jolly and Bolitho (2011) which we have found to be useful to both experienced and novice materials writers. It can help them to begin to understand the fundamental steps of materials development and how these same steps will occur in most contexts. The Jolly and Bolitho seven-step framework is summarized briefly below in Table 1 with examples from our own context.

Table 1

Example of the Steps of the Jolly \& Bolitho Framework for a Teaching Context

\section{Steps in Materials Development}

\section{Identification of a Need}

This informs us about the goal of the learning materials. What do the learners need to learn? Is it for general English, academic English, English for tourism, ESP, or some other area?

\section{Steps in Materials Development}

\section{Exploration of language}

What language functions, grammar, vocabulary, genre, and so on are required to fulfil the need?

\section{Contextual realization}

What is a suitable context for embedding the language practice tasks, for example, conversations, role plays, readings and so on?

\section{Pedagogical Realization}

How are the materials actually going to be used in the classroom in a way that will achieve the goal?

\section{Physical Production}

Create the materials in paper or digital

form in a way that can be accessed by learners.

\section{Use in Classroom}

Use the learning materials in the

classroom with the students. university entrance; they need to critically evaluate and express their opinions on issues and challenges facing the world.

\section{Evaluation of Materials}

How and when will the materials be evaluated?

\section{Contextualized Example}

Topic vocabulary (gender issues, environment, leaders)

A realistic discussion scenario would enable students to learn about the policies of various countries regarding challenges facing the world and to then express their opinions on these challenges.

Learning materials set up to simulate a G7 Summit meeting with each student being assigned a role as leader of one of the countries. Students are given time to research and prepare a short speech on their assigned country's policies on global issues, asked to research other members' policies, and to prepare questions to ask the various leaders. To conclude, students express their personal opinions on how best to tackle these problems.

Instruction and preparation sheets given to students and name plates and country flags displayed to provide a realistic environment.

Students have a round table discussion starting with their brief speech, followed by questions and ending with each student's opinion on the issue.

Evaluation of the materials to be conducted pre-, during- and post-activity. 
Material designers can use this framework as a practical tool in conceptualizing and addressing the challenges and steps in creating their own learning materials. The research questions and methodology for this study are outlined below.

\section{The Study and Research Questions}

While it is clear that materials design frameworks provide a useful way to conceptualize materials design, it is not so clear about the inclination of teachers in Japan to create materials rather than relying on textbooks, whether they make use of such materials design frameworks, whether these frameworks help to face the actual challenges of creating materials, and the actual steps that teachers follow in creating materials in the real world rather than the idealized world of the framework. Subsequently, the aim of the study was to explore a) teacher views on textbooks as opposed to teacher developed materials, b) the challenges faced by teachers when developing materials, c) the materials development process that writers follow, and whether a materials framework is used or not used. To explore these themes, the following research questions were addressed:

RQ1. Do teachers feel that coursebooks meet the needs of their students, or would they prefer to develop their own materials?

RQ2. What do teachers find most challenging about developing their own materials?

RQ3. Do teachers follow a materials development framework when designing their materials?

\section{Method}

An anonymous questionnaire was designed using both open- and closed- ended questions (See Appendix A for the questionnaire and Appendix B for the respondents' biodata). In total, $20(\mathrm{~N}=20)$ teachers responded to the questionnaire. However, as all the questions were optional, there were respondents who left some questions unanswered. Additionally, there were occasions of overlap when respondents answered the questions. For example, some teachers indicated they worked at both a junior high school and a high school. Due to an absence of previous research into the materials development processes of language teachers, these questions were used to establish each respondent's teaching context and experience and to collect data to answer the research questions. The questionnaire titled "Materials Development Questionnaire" was distributed to English teachers in Japan through social media platforms such as Facebook and personal contacts. Snowball sampling was also conducted by asking participants to share the questionnaire with their own contacts. The questionnaire was designed using Google Forms and the data collated automatically in a spreadsheet.

\section{Teaching Context}

\section{Findings and Discussion}

Figure 1

Teaching Contexts of the Respondents.

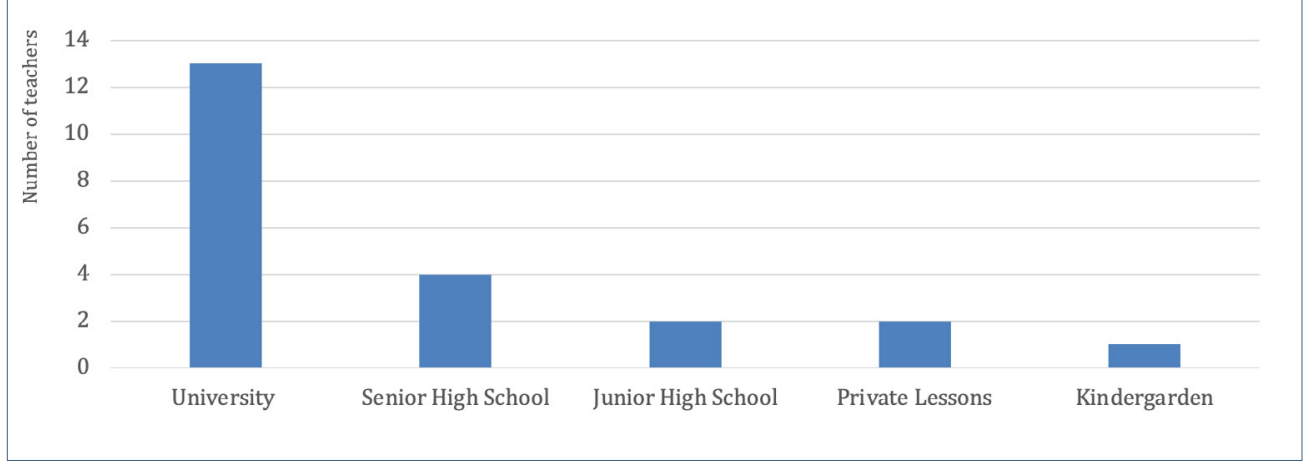

As can be seen from Figure 1, the majority of respondents are currently employed at university level with the next largest group working at senior high schools. Figure 2 shows that most of the respondents are very experienced in materials development with almost $90 \%$ having more than seven years' experience in designing materials for use in their teaching contexts. The remaining $10 \%$ indicated less than one year of materials development experience. One thing to note is that the high level of experience may indicate a prior interest in materials development which resulted in more experienced materials developers taking the questionnaire and possibly leading to a self-selection bias. 
JALT2020

COMMUNITIES OF
TEACHERS \& IEARNERS

Figure 2

Experience Developing Own Materials

\begin{tabular}{|c|c|c|c|c|}
\hline \\
\hline \multirow{2}{*}{\multicolumn{4}{|c|}{12}} & \\
\hline & & & & \\
\hline \multicolumn{4}{|l|}{ 密 10} & \\
\hline & \\
\hline \multicolumn{4}{|l|}{ 吾 4} & \\
\hline \multicolumn{5}{|l|}{$\bar{z}_{2}$} \\
\hline 0 & 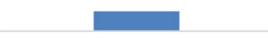 & 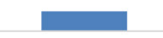 & & \\
\hline & $\begin{array}{l}\text { I have never developed my } \\
\text { own materials }\end{array}$ & Less than 1 year & $7-10$ years & Over 10 years \\
\hline
\end{tabular}

RQ1. Do teachers feel that coursebooks meet the needs of their students, or would they prefer to develop their own materials?

As shown in Figure 3 below, the majority of respondents are satisfied and feel that the textbook they are currently using is somewhat to very much meeting the needs of their students. This initially seems to be in strong contrast to the finding of Tomlinson (2010) that $78 \%$ of ESL teachers surveyed were not satisfied with the coursebook they were using. However, only one respondent believes the textbook is comprehensively meeting the needs of their students, and further caveats are noted below.

Figure 3

Satisfaction that Coursebook is Meeting the Needs of Students

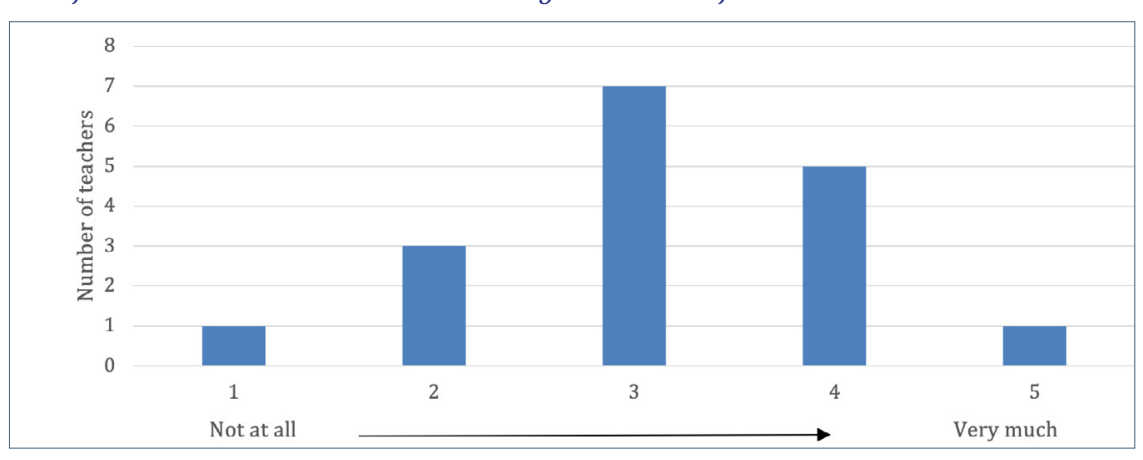

The follow up open question, "Given the choice, would you prefer to use a coursebook or develop your own materials?" provided a deeper insight into teachers' attitudes towards textbooks as opposed to their own developed materials. The overwhelming majority of teachers indicated that given the choice, they would prefer to develop their own materials. The rationale for this is shown by some of the responses below.

Respondent 2 said that "I would prefer to develop my own because no textbooks can satisfy my needs." While it is unclear here whose or what kind of satisfaction is meant, respondent 4 gives a much more informative answer: "By far I prefer to use my own materials. Getting to know my students well and target their specific needs is a key part of my teaching strategy. Having materials l've designed from the inside-out to target those needs means that they are much more effective during limited classroom times. The downside being that it can take a lot of time to 'learn' a student that well."

Clearly, teachers are trying to satisfy the specific needs of the students in the classroom in front of them. Respondent 8 gives one reason which corroborates Maley's (2011) assertion that teachers believe textbooks cannot satisfy local needs when they reply "Develop my own stuff, every time, no question. Every coursebook I ever used seemed to contain wildly disparate units cobbled together and presented as a 'unified whole' that barely contained a thread of unity." While ESL publishers are certainly able to produce a "unified whole", it is not necessarily one that can satisfy the needs of any particular group of students.

Other respondents are content with using a textbook but hope for some freedom to develop their own materials. Respondent 1 says that "the course book acts as a base that can be expanded upon by individual teachers." Respondent 11 also sees the textbook as a resource, useful but insufficient: "I would ... ideally spend three lessons on the course book, and every fourth lesson doing activities with my own materials and tasks."

Other respondents prefer to use and rely on a textbook. Respondent 3, a university teacher with ten years' experience, gives time as the reason: "I don't mind making supplementary materials, but for a whole course? I wouldn't have time."

Despite anecdotal evidence to the contrary, the majority of teachers surveyed reported being satisfied with the coursebook they are currently using. However, when probed more deeply about their preference, most teachers agreed to a preference for developing their own materials. These two data sets appear slightly contradictory and may suggest that with an increasing choice of teaching materials available, educators are able to source resources that more closely align with their teaching context than has been the situation in the past. 
JALT2020

COMMUNITIES OF
TEACHERS \& IEARNERS
$R Q$ 2. What do teachers find most challenging about developing their own materials?

Figure 4 shows the major difficulties teachers encounter when developing their materials.

Figure 4

Major Difficulties when Designing Own Materials

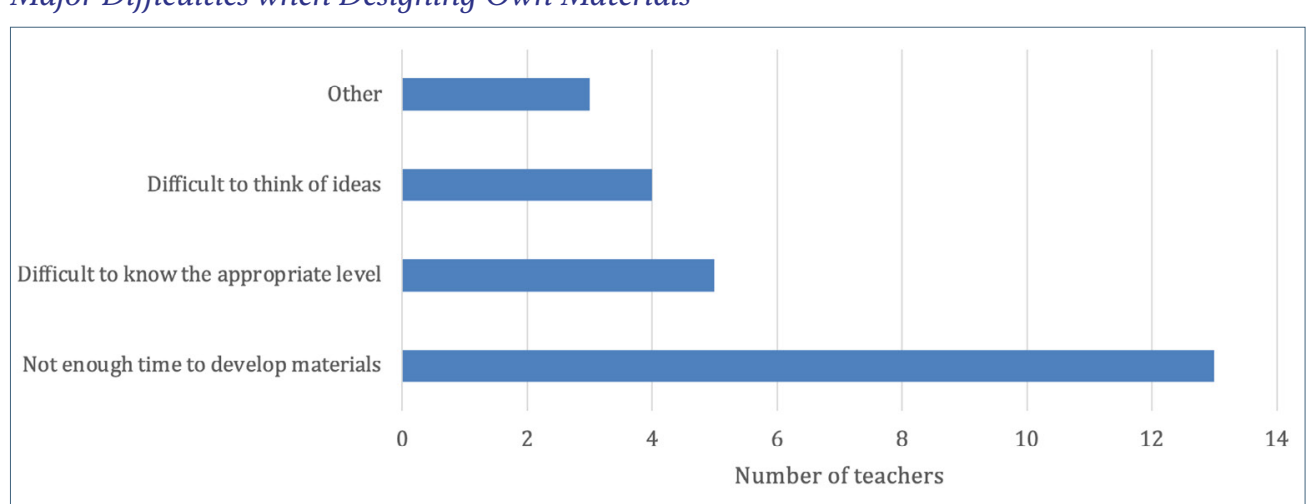

It is obvious from the responses that the main difficulty with materials development is a limited amount of time in which to generate them. This reason is followed by some respondents finding it difficult to establish their students' level with other teachers struggling with creativity in developing appropriate materials. Of the teachers that responded "other" one questioned the benefit of dedicating much time to creating materials that may not be used again. Another commented that their lack of expertise in technology makes it difficult to produce engaging materials.

RQ3. Do teachers follow a materials development framework when designing their materials?

Figure 5 shows that in response to Have you ever used a framework to help create ESL materials?, the answers were divided with 55\% answering Yes and 45\% answering No.
Figure 5

Have You Ever Used a Framework to Help Create Your ESL Materials?

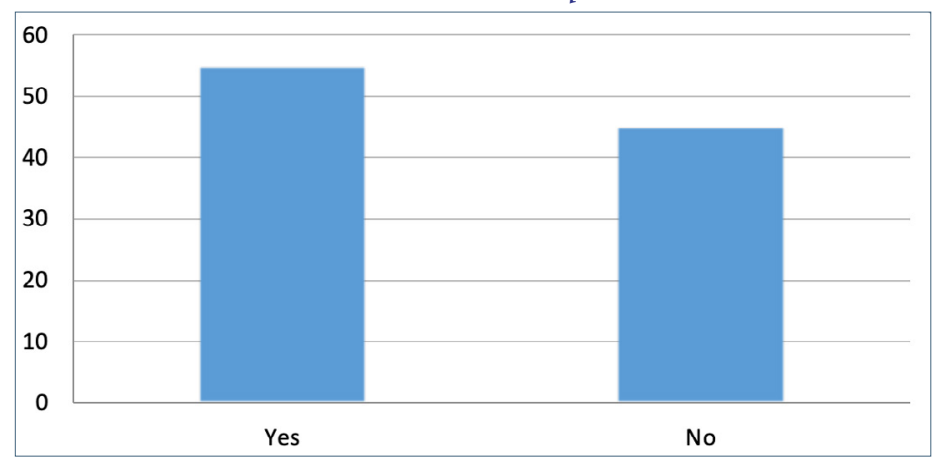

To understand the materials writing processes of the respondents, the materials development processes described by the respondents were divided into different approaches. There is of course considerable overlap between these approaches and most materials developers probably use a little of each.

\section{Theory-Informed Approaches}

Some of the teachers are already well aware of materials development literature and development frameworks. For example, Respondent 4 says that "my approach has a lot of adaptation from Brian Tomlinson's Developing Materials for Language Teaching."

Others have developed their own approaches through trial and error but recognize a lot of the same steps within the established framework. For example, Respondent 7 says, "Though this is my first time to be introduced to the framework, it seems that I have been using the steps." This convergence of practical experience and the theoretical framework is to be expected in materials development more than many areas of foreign language pedagogy since materials development is fundamentally a practical area and even the theory of the framework is simply a description of the steps that have been followed in practice.

\section{Practical Approach}

Other teachers have little interest in theory or even seeing how the framework can be useful. Instead, they are very goal-driven. One participant summarized as "Goal 
first, realistic journey to get there, non-linear, try a few things in class, see what sticks, build from there." This nonlinear classroom-driven route may not be the fastest way to produce materials, but it can be highly effective in addressing the changing and highly specific needs of any particular student or group of students. Even Jolly and Bolitho recognized that their own framework was non-linear and jumped back and forth from stage to stage.

\section{Curriculum-Driven Approach}

A third type of response was from teachers who have less freedom because of a curriculum imposed by their school or education board. For example, Respondent 10 says that "after checking the curriculum, I identify topics covered and then create materials to make class more personalized for the students I am teaching." Similarly, Respondent 17 comments that the common materials development pattern is to: "Follow the monthly/seasonal theme, work in grammar, plenty of hands on for young learners and repetition using various senses to reinforce new grammar, making it fun to learn." And Respondent 19 says, "If following a curriculum then use that as a starting point for the subject matter, then focus on what I want to achieve (the goal) then try and make the material relevant to the students' needs and try to make the material educational as well as motivating."

These three respondents paint a very clear picture of how they are being creative in fulfilling the specific needs of their students while also working within the constraints of the larger imposed curriculum. This is probably one of the most common situations in Japan, and knowing a materials development framework may help teachers to better conceptualize how to walk this fine line between constraint and specific needs. As Jolly and Bolitho $(2011$, p. 113) say "it can allow us to deal in a concrete way with the reasons for the failure of language materials and provide us with clues to their improvement."

\section{Guided by Own Interest}

A fourth type of response was given by teachers who were driven more by their own interest rather than by the specific needs of students. For example, Respondent 3 says: "First, I find a topic that interests me, secondly, consider how to introduce the topic either through a picture, song, brainstorm or questions and answers. After that, develop in stages, let the process work by itself a bit but as each stage develops, make sure there is a task to complete. Review the topic often and ask yourself questions along the way.” While this focus on self-interest rather than student needs may seem to be self-indulgent for a teacher, it is also useful to keep in mind that students tend to be motivated most by teachers who are highly interested in their subject. Research conducted by Mahler et al. (2018) has shown a significant positive relationship between teachers' subject-specific enthusiasm and student performance.

The responses to RQ3 show that there are variations between teachers when developing materials. Just over half report having adhered to a materials development framework, with just under half having never sought guidance from one. While the majority of respondents indicate they have a goal when developing their materials, it is noteworthy that none mention the other stages of materials development, such as language exploration and evaluation of materials used. The absence of a mention of the evaluation of materials stage is concerning as it is something that Jolly and Bolitho (2011) strongly advise teachers to practice, as in their view, materials development is a dynamic process. The evaluation step allows teachers to revise, adapt and reuse materials in subsequent lessons and its inclusion can lessen a possible view held by some educators that materials development is an inefficient endeavor insofar as they require a substantial investment of time, yet they are static and non-recyclable.

\section{Limitations}

We acknowledge that this study has a number of limitations. Firstly, the number of respondents is small, and it would be beneficial to replicate it with a greater number of ESL teachers in Japan. A further shortcoming of this research is that it is not representative of the diverse nature of the ESL environment within Japan as the majority of respondents are experienced teachers working in the university sector with a preexisting interest in materials development. In future research or replication studies, it is suggested that a wider sample is obtained by connecting with existing organizations such as JACET, local JALT chapters, or JALT SIGs including the Teaching Younger Learners SIG or the School Owners SIG. Additionally, the word "framework" as it is related to materials development was not clearly defined in the questionnaire and this may have resulted in respondent confusion. Subsequent research should eliminate any misunderstanding by explicitly stating the meaning of "framework" and providing an example. Finally, while analyzing the results, it became apparent that Question 3 and Question 5 did not fully exploit the respondents' answers. These questions would have benefitted from a 5 -point Likert scale that allowed for greater variation and subsequently a more accurate analysis. While Question 3 could have contained a follow-up question requesting an explanation of the answer. 


\section{JALT2020}

COMMUNITIES OF
TEACHERS \& IEARNERS

\section{Conclusion}

Despite its limitations, the study does provide a glimpse into materials development among ESL teachers in Japan with the findings highlighting a preference for selfdeveloped materials among teachers. However, there is a clear discrepancy between teachers who are guided by a materials development framework and those that are not. While it is encouraging that most teachers admit to having a goal as a starting point for their materials development, they should be conscious that while a necessity, a goal is only one part of the journey of materials design. Whether using a materials framework or not, teachers could achieve greater performance in time management if they considered other parts of the process, especially making an evaluation stage a staple of their design process. For both experienced and novice materials writers, a very accessible framework that can ensure they adhere to all the steps in the process is the one offered by Jolly and Bolitho.

\section{Bio Data}

Niall Walsh is a full-time lecturer at Nagoya University of Foreign Studies. His primary research interests include literature in language teaching, materials development and written corrective feedback. <mullingarman@gmail.com>

Brian Cullen is a professor at Nagoya Institute of Technology. His research interests include materials development, educational psychology, and the use of music in the classroom. <cullen.brian@gmail.com>

\section{References}

Jolly, D., \& Bolitho, R. (2011). A framework for materials writing. In Tomlinson, B. (Ed.), Materials development in language teaching (pp. 107-134). Cambridge University Press.

Mahler, D., Großschedl, J., \& Harms, U. (2018). Does motivation matter? The relationship between teachers' self-efficacy and enthusiasm and students' performance. PloS one, 13(11), 1-18. https:// doi.org/10.1371/journal.pone.0207252

Maley, A. (2011). Squaring the circle-reconciling materials as constraint with materials as empowerment. In Tomlinson, B. (Ed.), Materials development in language teaching (pp. 379-402). Cambridge University Press.

McDonough, J., \& Shaw, C. (2003). Materials and methods in ELT: A teacher's guide. Blackwell Publishing.

Mishan, F., \& Timmis, I. (2015). Materials development for TESOL. Edinburgh University Press.
Tomlinson, B. (2010). What do teachers think about EFL textbooks? Modern English teacher, 19(4), 5-9.

Tomlinson, B. (Ed.). (2011). Materials development in language teaching ( $2^{\text {nd }}$ ed.). Cambridge University Press.

Tomlinson, B., \& Masuhara, H. (2018). The complete guide to the theory and practice of materials development for language learning. John Wiley \& Sons.

\section{Questionnaire}

\section{Appendix A}

Q1. Where do you work?

- University

- Senior High School

- Junior High School

- Elementary School

- Kindergarten

- English Language School

- Private Language Teacher

- Other

Q.2 How much experience do you have in developing your own ESL materials?

- less than 1 year

- 1 - 3 years

- 4 - 6 years

- 7 - 10 years

- Over 10 years

- I have never developed my own materials

Q3. Have you ever used a framework to help create your ESL materials?

- Yes

- No 


\section{JALT2020}

COMMUNITIES OF

Walsh \& Cullen: Materials Development Frameworks and the Challenges of Developing Learning Materials
Q4. Please describe your typical materials development process.

Q5. What do you find most challenging about materials development?

- Not enough time to develop materials

- Difficult to think of ideas for materials

- Difficult to know the appropriate level for students

- Other

Q6. If 'Other' to question 5, could you please explain the reason?

Q7. Given the choice, would you prefer to use a coursebook or develop your own materials? Explain.

Q8. If you use a coursebook, how well do you feel the coursebook is meeting the needs of your language learners?

Q9. Do you feel supported by your working environment in creating your own materials?

- Yes

- No

- Sometimes

Q10. Any other comments about materials development?

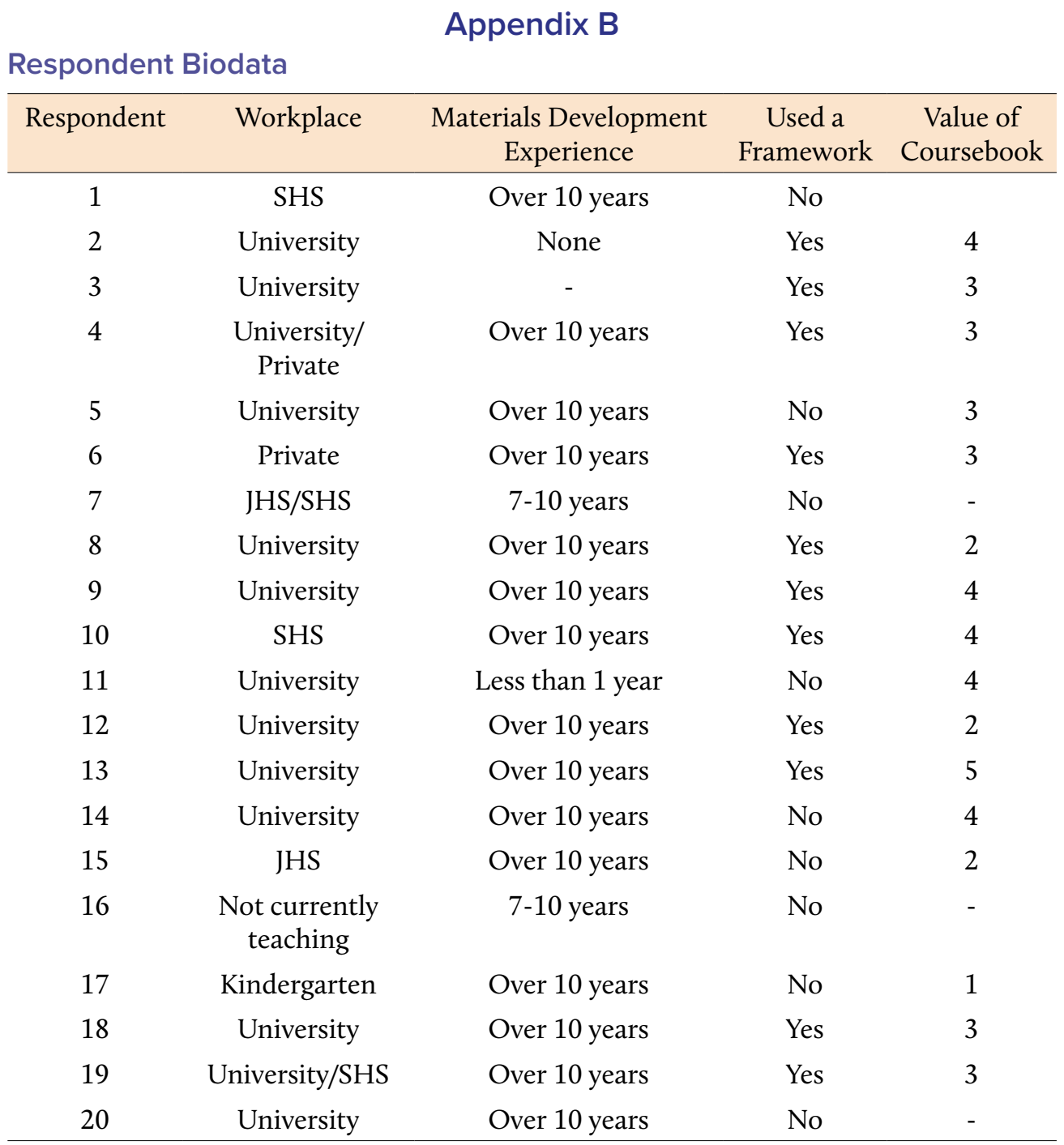

